\title{
ОСОБЕННОСТИ АДВОКАТОВ КАК СУБЪЕКТОВ, ОКАЗЫВАЮЩИХ ЮРИДИЧЕСКУЮ ПОМОЩЬ ВОЕННОСЛУЖАЩИМ
}

\section{FEATURES OF LAWYERS AS SUBJECTS PROVIDING LEGAL ASSISTANCE TO MILITARY PERSONNEL}

\section{Yu. Kocheulov}

Summary. In modern conditions of geopolitical tension and instability, the institution of the army is a pillar of the country's independence both in the foreign political arena and within the state. People are the backbone of any army in the world, therefore, the state should in every possible way contribute to the protection of the rights of military personnel. The constitutional right to receive qualified legal aid is one of the basic rights and freedoms that determine the democracy index of a modern rule of law. This article will identify the features and distinctive features of lawyers as the main subjects of the provision of qualified legal assistance, as well as identify problems that arise when lawyers implement this assistance to military personnel.

Keywords: serviceman, qualified legal assistance, protection of the rights of servicemen.

\author{
Кочеулов Юрий Юрьевич \\ Аспирант, Московский государственный \\ юридический университет им. О.Е. Кутафина \\ kocheulovmu@gmail.com
}

Аннотация. В современных условиях геополитической напряженности и нестабильности институт армии является опорой независимости страны как на внешней политической арене, так и внутри государства. Опорой любой армии мира составляют люди, следовательно, государство должно всячески способствовать охране прав военнослужащих. Конституционное право на получение квалифицированной юридической помощи является одним из базовых прав и свобод, которые определяют индекс демократии современного правого государства. В данной статье будут выявлены особенности и отличительные черты адвокатов как основных субъектов оказания квалифицированной юридической помощи, а также выявлены проблемы, возникающие при реализации адвокатами указанной помощи военнослужащим.

Ключевые слова: военнослужащий, квалифицированная юридическая помощь, защита прав военнослужащих.

Указанное право является одним из центральных элементов всего конституционного набора прав и свобод человека.

Согласно ч. 2 ст. 48 Конституции Российской Федерации каждое лицо, задержанное, заключенное под стражу, обвиняемое в совершении преступления имеет право пользоваться помощью адвоката с момента соответственно своего задержания, заключения под стражу или предъявления обвинения.

Таким образом, в рамках уголовного производства, касательно вышеуказанных субъектов получения правовой помощи, Конституция связывает право на получение квалифицированной правовой помощи непосредственно с деятельностью адвокатуры.

Стоит отметить, что адвокат не является единственным субъектом оказания юридической помощи военнослужащим. При этом, если мы говорим о субъектах, которые оказывают «квалифицированную» юридическую помощь, то адвокату отводиться центральная роль ввиду следующего: 
Во-первых, адвокатура, как институт гражданского общества, не входит в систему государственных органов и органов местного самоуправления, а является полностью независимым образованием. Таким образом, адвокаты выступают независимыми субъектами оказания квалифицированной юридической помощи, в том числе военнослужащим. Указанный признак является важнейшей отличительной чертой адвокатуры. Ведь, когда речь идет об армии, необходимо учитывать особый характер института армии, где все построено на четкой иерархии и субординации, а также принципе единоначалия, согласно которому командир (начальник) наделён всей полнотой распорядительной власти по отношению к подчинённым. Таким образом, представляется верным предположить, что в правовом государстве подчиненный не должен защищаться от притеснения со стороны руководителя последним. В противном случае открывается огромный простор для злоупотребления.

Во-вторых, адвокатскую деятельность можно охарактеризовать как квалифицированную юридическую помощь, тогда как адвокат - это лицо, которое получило в установленном Ф3 «Об адвокатуре и адвокатской деятельности» соответствующий статус.

Профессиональную деятельность, по мнению автора данной статьи, может вести лишь лицо, которое получило базовую теоретическую и основанную на ней практическую подготовку. Данное предположение подтверждается и тем фактом, что статус адвоката в Российской Федерации может получить лицо, которое имеет высшее юридическое образование, полученное по имеющей государственную аккредитацию образовательной программе, либо ученую степень по юридической специальности, а также имеющее стаж работы по юридической специальности не менее двух лет либо прошедшее стажировку в адвокатском образовании в сроки, установленные Ф3 «Об адвокатуре и адвокатской деятельности» и сдавшее соответствующий экзамен.

Как отмечает Г.М. Резник «квалифицированной» в соответствии с мировой практикой может считаться такая помощь, которая оказывается специалистами по праву - как минимум лицами, имеющими юридическое образование, при обязательном соблюдении профессиональных стандартов и норм этики, в соответствии с соответствующим профессиональным контролем. Вне этих стандартов и норм юридическая помощь квалифицированной признана быть не может» [3].

B-третьих, специфика оказания адвокатами юридической помощи проявляется в наличии механизма адвокатской тайны, что проявляется в отношении всех субъектов ее получения, в том числе военнослужащих.
Как указано в п. 2 ст. 8 ФЗ «Об адвокатуре и адвокатской деятельности», адвокат в Российской Федерации не может быть вызван и допрошен в качестве свидетеля об обстоятельствах, ставших ему известными в связи с обращением к нему за юридической помощью или в связи с ее оказанием.

П. 3 указанной статьи устанавливает, что лишь суд устанавливает возможность проведения оперативно-розыскных мероприятий и следственных действий в отношении адвоката.

Важность института адвокатской тайны проявляется в делах военнослужащих, связанных с государственной/ военной тайной, в том числе в делах о шпионаже. Следовательно, наличие механизма адвокатской тайны позволяет адвокату в полной мере реализовать свои функции по защите военнослужащего.

В-четвертых, на адвокатов распространяются нормы Кодекса профессиональной этики адвоката.

Кодекс профессиональной этики адвоката устанавливает обязательные для каждого адвоката правила поведения при осуществлении адвокатской деятельности, основанные на нравственных критериях и традициях адвокатуры, на международных стандартах и правилах адвокатской профессии, а также основания и порядок привлечения адвоката к ответственности [4].

В силу ч. 1 ст. 18 Кодекса профессиональной этики адвоката нарушение адвокатом требований законодательства об адвокатской деятельности и адвокатуре и указанного Кодекса, совершенное умышленно или по грубой неосторожности, влечет применение мер дисциплинарной ответственности.

Как указал Конституционный суд, Кодекс является корпоративным нормативным актом, что, в свою очередь, не означает, что положения данного акта не могут применяться какими-либо другими субъектами правоотношений [5].

Следовательно, нормы Кодекса профессиональной этики должны распространяться на иных субъектов при оказании последними юридической помощи, например на наемного юриста, представляющего интересы военнослужащего в рамках гражданского процесса. Но на практике вышеуказанные разъяснения Конституционного суда носят больше декларативный характер, так как нормы дисциплинарной ответственности, установленные Кодексом, применяются исключительно к адвокатам.

Между тем, согласно Сведениям об адвокатуре и адвокатской деятельности в Российской Федерации, 
опубликованным Федеральной палатой адвокатов Российской Федерации в 2020 году, за 2019 год к дисциплинарной ответственности было привлечено 2876 адвокатов [8]. Для сравнения: в 2018 году данный показатель равнялся 3173 привлеченного к дисциплинарной ответственности адвоката, в 2017 году данный показатель равнялся 3048 привлеченных к дисциплинарной ответственности адвокатов [7].

В-пятых, в силу ст. 49 Уголовно-процессуального кодекса защиту прав и интересов подозреваемых и обвиняемых осуществляют адвокаты и только они. Указанное положение наделяет адвокатов исключительным значением в рамках уголовного судопроизводства.

Согласно Сведениям об адвокатуре и адвокатской деятельности в Российской Федерации, опубликованным Федеральной палатой адвокатов Российской Федерации в 2020 году, за 2019 год для участия в уголовном судопроизводстве по назначению было привлечено 33 994 адвокатов [8].

Проблемы реализации адвокатами правовой помощи. В настоящее время Конституция Российской Федерации содержит необходимую норму права, гарантирующую военнослужащим право на квалифицированную юридическую помощь, однако подзаконное законодательство в области реализации данного права требует детальной доработки. [2]

Ч. 1 ст. 48 Конституции Российской Федерации, гарантирующая предоставление квалифицированной юридической помощи в предусмотренных законом случаях бесплатно, напрямую связана именно с военнослужащими, проходящими службу по призыву, а законом, обеспечивающим её реализацию, является Федеральный закон «О статусе военнослужащих». Между тем, специальное военное законодательство не содержит положений, регулирующих вопросы оказания правовой помощи, оказываемой адвокатами военнослужащим, проходящих военную службу по контракту. Значительная часть военнослужащих лишена доступа не только к бесплатной, но и к платной юридической помощи в силу своего проживания в удаленных и малонаселенных районах, где нет или недостаточное количество адвокатских образований. Законодательно не решена проблема оказания помощи адвокатами на территории иностранных государств.

Отсутствуют стандарты качества бесплатной юридической помощи военнослужащим, а также действенные механизмы, ее обеспечивающие.

В настоящий же момент отсутствует системный, единый комплексный подход к проблемам, решение кото- рых необходимо для обеспечения права на получение квалифицированной правовой помощи, не определен четкий механизм предоставления и объем такой помощи. По мнения автора настоящей работы, необходимо внести изменения в действующее законодательство. Логичнее внести соответствующие поправки в специальное военное законодательство, в частности в Ф3 «О статусе военнослужащих».

Стоит отметить, что не все инструменты профессиональной деятельности адвокатов являются реально эффективными. Так, согласно п. 3 ст. 6 Федерального закона «Об адвокатской деятельности и адвокатуре в Российской Федерации», адвокат вправе запрашивать необходимые документы или их заверенные копии, направив адвокатский запрос в органы государственной власти, органы местного самоуправления, различные общественные организации и объединения. Однако на практике указанное право имеет множество проблем при его реализации. Так, вплоть до 2016 года в законодательстве нашей страны не было санкции за неисполнение адвокатского запроса, что фактически делало его абсолютно недейственным инструментом. 02 июня 2016 г. Государственной Думой был принят Федеральный закон № 160 -Ф3 «О внесении изменений в статьи 5.39 и 13.14 КоАП РФ и Федеральный закон «Об адвокатский деятельности и адвокатуре», который внес существенные коррективы в регламентацию адвокатской деятельности, а также ввел административную ответственность за отказ от предоставления информации, запрошенной адвокатом.

Однако далеко не все проблемы были решены данным законом. В частности, согласно п. 1 ст. 6.1 адвокат имеет возможность направлять в государственные органы и органы местного самоуправления официальные обращения относительно предоставления справок, характеристик и иных документов, необходимых для оказания квалифицированной юридической помощи. Пункт 4 указанной статьи закрепляет круг данных, в получении которых адвокату может быть отказано, в их числе значатся сведения, отнесенные законом к информации с ограниченным доступом. Это, по мнению ряда исследователей, привело к тому, что указанный пункт служит легальным основанием для тех же органов и должностных лиц, которые ранее игнорировали адвокатские запросы, отказывать в предоставлении информации со ссылкой на то, что запрашиваемые сведения относятся к информации с ограниченным доступом [1].

Кроме того, ответственность за отказ в предоставлении информации адвокату на основании адвокатского запроса не является справедливой - от 5 до 10 тысяч рублей, что также не позволяет говорить о действенности механизма адвокатского запроса. Конечно, в случае 
отказа в предоставлении сведений по адвокатскому запросу, адвокат может затребовать запрашиваемые сведения через суд, а уже затем, в случае неисполнения судебного акта, воспользоваться институтом «астрента», но эта процедура требует значительных процессуальных издержек, поэтому не всегда является эффективной на практике.

Институт «астрента» больше характерен для банкротных дел и часто применяется судами в случае не передачи руководителями компаний-банкротов первичной и иной бухгалтерской документации должника арбитражному управляющему, например: Определение Арбитражного суда Самарской области от 25 июня 2015 года по делу № А55-5765/2015 г. [6]

Следовательно, на законодательном уровне необходимо увеличить штраф за неправомерный отказ в предоставлении сведений по адвокатскому запросу, внести соответствующие поправки в ст. 5.39 КоАП РФ.

Еще одной концептуальной проблемой адвокатской деятельности является ее непредпринимательский характер.

В силу ч. 2 ст. 1 Ф3 «Об Адвокатская деятельности и адвокатуре в РФ», адвокатская деятельность не является предпринимательской. Таким образом, все доходы адвокатского объединения или отдельного адвоката являются по своей правовой природе не результатом коммерческой или иной предпринимательской деятельности, а вознаграждением, выплачиваемым клиентом.

Непредпринимательский характер серьезно затрудняет развитие института адвокатуры, что особенно рельефно проявляется в сравнении с иными коммерческими юридическими фирмами, которые конкурируют между собой по законам рыночной экономики.

По мнению автора, корни «некоммерческого подхода» произрастают от негативного исторического отношения наших граждан к институту предпринимательства, где финансовый успех человека ассоциируется с обманом, с некой финансовой нечистоплотностью. Иное отношение к предпринимателям на западе, что находит свое отражение и на финансовой устойчивости западных компаний, в том числе юридических фирм. В мире имеются международные юридические компании с миллиардной капитализацией. При сегодняшнем подходе на такие цифры российским адвокатским образованиям рассчитывать не приходится даже при самом оптимистичном настрое.

Современной адвокатуре необходимо существовать по законам рынка: адвокатские образования должны иметь в своем штате маркетологов, финансистов, переговорщиков и иных лиц, которые осуществляют свою трудовую деятельность в рыночно-ориентируемой организации, в ином случае в скором времени она будет неконкурентоспособна в сравнении с иными субъектами, оказывающими юридическую помощь. Подход «И чтец, и жнец, и на дуде игрец» изжил себя. Из «некоммерческой адвокатуры» произрастают такие системные проблемы, как разнонаправленная судебная практика, связанная с выплатой «гонорара успеха», ограничения и споры связанные с маркетингом адвокатских услуг и иные проблемы, в первую очередь организационные.

Стоит отметить, что Верховный суд в своем Определении от 18.02.2015 по делу № А60-11353/2013 легитимировал гонорар успеха, не смотря на это в судах и у практикующих адвокатов возникаем множество споров о справедливости такого отлагательного условия.

Также действующим адвокатским образованием необходимо решить вопрос со специализацией: в современных условиях адвокаты общего профиля не всегда столь эффективны, как их коллеги, специализирующиеся на определенных правовых вопросах. Так, в Российской Федерации существуют специализированные адвокатские образования, оказывающие правовую помощь военнослужащим, например, «Специализированная Коллегия адвокатов по обслуживанию органов военной юстиции и оказанию правовой помощи военнослужащим» [9].

В силу ч. 1 ст. 18 Ф3 «Об адвокатской деятельности и адвокатуре в Российской Федерации», вмешательство в адвокатскую деятельность, осуществляемую в соответствии с законодательством, либо препятствование этой деятельности каким бы то ни было образом запрещаются.

Между тем, на практике права адвокатов и их доверителей регулярно нарушаются следственными органами, что является недопустимым. Так, согласно уже приведенной выше статистике, за 2019 год было выявлено 1115 случаев нарушения профессиональных прав адвокатов в Российской Федерации [8].

Еще одной проблемой реализации правовой помощи адвокатами военнослужащим является размер вознаграждения. В силу ч. 3 ст. 22 «О статусе военнослужащих», адвокаты оказывают юридическую помощь военнослужащим, проходящим военную службу по призыву, по вопросам, связанным с прохождением военной службы, а также по иным основаниям, установленным федеральными законами, в порядке, определяемом Правительством Российской Федерации. Не смотря бесплатный характер такой помощи, государство обеспечивает оплату деятельности адвокатов, пусть и в доста- 
точно формальных размерах. Размер и порядок оплаты адвокатских услуг регулируется на подзаконном уровне.

Нередко адвокаты вынуждены работать за весьма скромную сумму. Согласно Сведениям об адвокатуре и адвокатской деятельности в Российской Федерации за 2019 год в рамках государственной системы бесплатной юридической помощи было выполнено 118910 поручений. Одновременно с этим сумма финансовых средств, предусмотренных бюджетом субъекта РФ в отчетном периоде на оказание бесплатной юридической помощи гражданам РФ, проживающим на территории субъекта РФ, равнялась 128802 999, 2 рублей [8]. Таким образом, видно, что за каждое выполненное поручение в среднем адвокат получал около 1083 рублей.

Размер вознаграждения и компенсации расходов при оказании юридическими консультациями и коллеги- ями адвокатов юридической помощи военнослужащим, проходящим военную службу по призыву, по вопросам, связанным с прохождением военной службы, а также по иным основаниям, установленным федеральными законами, существенно занижен, что не стимулирует их качественную работу, что существенно влияет на качество работы адвоката. Кроме того, остаётся неопределённым, в каком объёме оказывается юридическая помощь, кто будет контролировать качество юридических услуг и оплачивать услуги защитника, если к военнослужащему, проходящему военную службу по призыву, применяется дисциплинарный арест [2].

Таким образом, в данной статье были рассмотрены основные аспекты, касающиеся оказания правовой помощи военнослужащим адвокатами. Ряд проблем, выделенных автором, требует глубокого анализа со стороны законодателя и незамедлительного решения.

\section{ЛИТЕРАТУРА}

1. Богданова Л.И. Проблема применения адвокатского запроса / Богданова Л.И., Вопросы науки и образования, 2018, 52-54 с.

2. Калашников В.А. Конституционно-правовое регулирование права военнослужащих на квалифицированную юридическую помощь: вопросы теории и практики: специальность (12.00.02) «Конституционное право, муниципальное право»: диссертация на соискание ученой степени кандидата юридических наук/ ГОУ ВПО «Военный университет Министерства обороны Российской Федерации» (Военный университет).— Москва, 2009.85 с.

3. Резник Г.М. К вопросу о конституционном содержании понятия «квалифицированная юридическая помощь / Резник Г.М. — Москва, Адвокат, 2007 , № 4.

4. «Кодекс профессиональной этики адвоката» (принят I Всероссийским съездом адвокатов 31.01.2003) // Российская газета, 5 октября, 2005 г. № 222.

5. Определение Конституционного Суда РФ от 17.02.2015 N278-0 «06 отказе в принятии к рассмотрению жалобы гражданина Демина Павла Александровича на нарушение его конституционных прав пунктом 9 части 3 статьи 82 Федерального закона «0 службе в органах внутренних дел Российской Федерации и внесении изменений в отдельные законодательные акты Российской Федерации» // СПС «КонсультантПлюс»

6. Определение Арбитражного суда Самарской области от 25 июня 2015 года по делу № A55-5765 // СПС «КонсультантПлюс»

7. Отчет о деятельности Совета Федеральной палаты адвокатов Российской Федерации за период с апреля 2017 года по апрель 2019 года. — Текст: электронный // Федеральная палата адвокатов Российской Федерации: [сайт].— URL: https://fparf.ru/upload/medialibrary/7ce/Otchet-Soveta-FPA_aprel-2017-g.-_aprel-2019-g.pdf (дата обращения: 18.02.2021).

8. «Сведения 06 адвокатуре и адвокатской деятельности в Российской Федерации» (утв. решением Совета Федеральной палаты адвокатов от 27.09.2013, протокол N1) // СПС «КонсультантПлюс»

9. Специализированная Коллегия адвокатов по обслуживанию органов военной юстиции и оказанию правовой помощи военнослужащим.- Текст: электронный // Адвокатская палата Новосибирской области: [сайт].— URL: http://www.advpalatanso.ru/advokatskie_obrazovaniya/reestr_kollegiy_ advokatov_i_buro/159 (дата обращения: 17.02.2021). 